\title{
O PENSAMENTO EXISTENCIAL DE HENRY DAVID THOREAU
}

\author{
HERIBERTO ARNS \\ Universidade Federal do Paraná
}

As onipresentes "paperback editions" de Kierkegaard, Jaspers, Heidegger, Sartre, Marcel, Tillich, Buber (1) não deixam dúvidas sôbre a larga disseminação da literatura existencialista nos Estados Unidos.

M. Friedman, (2) examinando a divulgação do pensamento de Martin Buber, constata que, em 1944, apenas duas obras haviam sido traduzidas para o inglês sendo que, em 1959, já constavam mais de vinte traduções de Buber, nos respectivos catálogos, além de antologias e obras que focalizavam o autor existencialista.

Em 1955, "The New Yorker" (3) prognosticava um rápido declínio do movimento existencialista. Dez anos mais tarde, "Time" (4) chegava à conclusão contrária constatando a presença "ubiquitous" do pensamento existencial.

fico. (5)

A influência da literatura existencialista é hoje um fato pací-

1. "On the speculative level its popularity can be discerned in the omnipresent paperback editions of Kierkegard, Jaspers, Heidegger, Sartre, Marcel, Tillich, Buber, and others". L. Swesney - EXISTENTIALISM: AUTHENTIC AND UNAUTHENTIC - The New Scholasticis.n. Vol.XL Jan., 1966.

2. Martin Buber: THE LIFE OF DIALOGUE, N. Y. 1960.

3. THE NEW YORKER - A. West, february 5, 1955, p. 104.

4. TIME, May 7, 1965, p. 70.

5. Veja-se, p. ex., o destaque com que uma obra de repercussäo, como é o excelente volume "The Modern Tradition", com o subtl tulo "Backgrounds of Modern Literature", lançado pela New York-Oxford University Press, editado no ano passacio, apresenta os corifeus do movimento existencialista: Soeren Kierkegard, Friedrich Nietzsche, Albert Camus, Jean-Paul Sartre, Martin Heidegger, Karl Jaspers, Martin Buber, Karl Barth, Paul Tillich. 
O existencialismo, autêntico ou inautêritico, domina hoje não só uma elite pensante como marca o pensamento e a vivência de todo uma geração. (6)

Vivemos numa era psicológica que justifica, mais e mais, a expressão: O Século do Mêdo.

Em face da presença do pensamento existencial, sobretudo no meio jovem americano (7) justifica-se que se voltem as atenções para autores da literatura norte-americana que anteciparam a interpretação da angústia existencial do homem moderno. Foi o que nos sugeriu a estudar H. D. Thoreau sob êsse aspecto sobremodo atual.

O Eremitão do WALDEN não constata apenas a angústia, mas procura inquirir-lhe as causas profundas. Escritor eclético, não apresenta um pensamento existencial sistemático. O pensamento fundamental, porém, não é outra coisa senão a constante: Salvar o Conteúdo da Vida, a Consciência Existencial. Daí sua problemática fundamental: "Where I lived, and what I lived for", O Acidental e o Essencial, o Tempo e o Ełerno, a Angústia do Homem das Massas, o Sentido da Solidão, enfim, a problemática da Entelequia da Existência do Homem.

\section{O Babitismo e a Trapa}

Um dos tipos mais característicos do homem americano é, sem dúvida, o "keep-smiling Yankee", o "self-made-man" que Emerson já caracterizava como esperto, ponderado e audacioso. Sua mais marcante qualidade é a Eficiência, expressão de organização técnica, espírito ativista, empreendedor, consciência de sucesso que o americano revela na realização de seus proịetos e de suas metas pessoais e nacionais.

Existe, porém, embora mais anônimo talvez, o americano introvertido místico, angustiado. E a "trapa" que se esconde entre as mas. sas descrertes do processo e do sucesso da civilização moderna.

Ambos os tipos tem sua origem, longinqua, na formação histórica do homem americano: O tipo renascentista, aventureiro, liberal, ativista de Jamestown já se distinguia, nos primórdios da história co

6. "How has the New Breed come to be?... It lives in the midst of a psychological age when the Sunday magazines talk about existencialism. It has read the philosophy and literature of the day, with its heavy emphasis on significance and personalism". A. Greeley, "A New Breed", AMERICA, May 23, 1964, p. 708, Ibid. L. Sweeny.

7. "If we confine our attention to America, its influence can be detected on the practical level in the Free Speech Movement which dominated the campus of the University of California at Berkeley in the 1964-1965 Schoolyear". Ibid. L. Sweeny. 
lonial americana, do peregrino e puritano místico, o integrista, teo crático, introvertido de New England. O antagonismo de ideologias. de concepção de vida que marca o princípio da Idade Moderna, caracteriza o próprio nascimento do mundo americano.

Quando Benjamin Franklin abandonou o Estado Teocrático dos Peregrinos e se dirigiu a Filadélfia, e lá iniciou a pregação do evangelho da prosperidade, confôrto, segurança, da eficiência, delineou êle a filosofia que haveria de nortear não apenas o crescimento de uma cidade, mas de toda uma nação. $E$, quando Emerson, um século mais tarde, se insurgia contra o dogmatismo puritano, contra $\circ$ enclausuramento religioso, não abandonava êle a atitude dos Peregrinos da Baía de Massachussets, mas a ampliava e aprofundava para abrir perspectivas mais universais para uma mística essencialmente americana.

O epíieto com que Thomas Carlyle qualificou a Franklin como "Pai de todos os Yankees" resume um aspecto que o "Babbitt" de Sinclair Lewis expressou em termos do século XX: "De vez em quando costumo sentar-me naturalmente e olhar êste sólido Cidadão Americano, com enorme prazer..." (*) De fato, "The Way to Wealth" tornou-se mais que um catecismo da Eficiência, um verdadeiro pedagogo para o americano à procura de sua auto-realização como Homem e como Nação. Há, porém, outro aspecto no gênio do homem americano. Emerson assim o interpreta: "Cabe-me convidar os homens mergulhados no Tempo a se recobrarem e sairem do Tempo, saboreando seu imortal ar nativo... Cabeme indicar constantemente, embora todo indigno, a Vida Ideal e Santa. O Bem Esquecido, a Causa Esquecida, em que nos debatemos e pecamos. Cabe-me experimentar a mágica da autenticidade, êsse luxo permitido apenas a reis e poetas. Cabe-me celebrar as faculdades espirituais em seus infinitos contrastes com os poderes mecânicos e a filosofia mecanicista dêste tempo". (DIÁRIO, 1837).

A experiência de "The Brook Farm", inspirada no Pensamento Emersoneano, representa a angustiante vocação claustral da América angustiada pela eficiência de seu progresso. É que "o babitismo não impediu a trapa", na expressão do sociólogo Munhoz da Rocha Neto. (8)

O mais autêntico dos rebeldes transcendentalistas americanos é. sem dúvida, Henry David Thoreau, inconformado com o progresso da civilização da América. E Thoreau, o iconoclasta que se insurgiu

(") confr. "...other directed, hidden-persuaded, waist-high cultured organization Man" (Babbitt) R.W. Horton "A Literatura Norte-Americana e Sem Espírito" Coimbra, 1962.

8. MENSAGEM DA AMERICA - Imprensa da Universidade do Paraná. 
contra tôdas as instituições que distorcem o conceito da Vida e corrompem a autenticidade do Homem. Thoreau opõe ao conceito do progresso e da eficiência, do "babitismo", a necessidade de uma nova atituaie de espírito.

\section{- Pânico da Civilização}

Quando, a 4 de julho de 1845, no “Independence Day", H. D. Thoreau abandonou a civilização para construir sua cabana no meio das florestas, êle não fez outra coisa senão executar, com intransigência, seu protesto contra a caricatura do progresso humano e restabelecer um humanismo baseado na Consciência da Vida, na sua primitiva beleza: "Fui morar na floresta, pois queria Viver com deliberação enfrentando sòmente os fatos essenciais da vida e vendo se podia aprender suas liçōes; evitaria assim, ao chegar a morte, descobrir que não havia vivido... Não quis conhecer o que não fôsse a Vida, - Viver é tão caro -; nem ter resignação alguma além do que me fôsse estritamente necessário. Queria viver largamente, sugar tôda a medula da Vida. Viver com firmeza, de modo espartano, afugentando tudo que fôsse supérfluo; cortar um talho profundo, raspar - essencial, encurralar a vida num canto e reduzí-lo a seus mínimos têrmos. E se se provasse vil, extrair então toda sua genuina vileza. E se fôsse sublime, conhecê-la bem, ser capaz de fornecer dela uma descrição completa. (9)

Paul Tillich, em "The Meaning of Meaningless", lamenta que o homem do século $X X$ perdeu o sentido profundo do Mundo e do EU, porque vive "in meanings out of a spiritual center". (10) 0 ho-

9. "I went to the woods because I wished to live deliberately, to front only the essential facrs of life, and see if I could not learn what it had to teach, and not, when I came to die, discover that I had not lived. I did not wish to live what was not life, ling is so dear; nor did I wish to practise resignation, unless it was quite necessary. I wanted to live deep and suck out all the marrow of life, to live so sturdily and Spartan. like as to put to rout all that was not life, to cut a broad swath and shave close, to drive life into a corner, and reduce it to its lowest termes, and, it it proved to be mean, why then to get the whole and genuine meanness of it, and publish its meanness to the world; or if it were sublime, to know it by experience and be able to give a true account of it... "WALDEN" - H. D. Thoreau p. 81-82 The Modern Library - New York 1950 Trad. de V. B. Delayti "Thoreau - O Rebelde de Concord" - GRD-1964.

10. Paul Tillich em "The Modern Tradition" by R. Ellmann and Ch. Feidelson - N.Y. Oxford University Press, 1965: "Twentieth-century man has lost a meaningful world and a self which lives in meanings out of a spiritual center. The man-created world of objects has drawn into itself him who created it and who now loses his subjectivity in it. 4 e has sacrificed himself to his Pown productions. But man still is aware of what he has lost or is continuously losing. He is still man enough to experience his deshumanization as despair. He does not Know a way out but he tries to save his humanity by expressing the situation as without an "exit He reacts with the courage of despair, the courage to be as oneself. Every analyst of present day Existentialist philosophy, art, and literature can show their ambiguous structure: the meeningless which drives to despair, a passionate denunciation of this situation, and the successful or usuccessful attempt to take anxiety of meaninglessness into the courage to be as oneself". 
mem sacrificou a si mesmo às suas próprias produções. $O$ trágico está em que, tendo perdido seu mundo, o homem conserva ainda a consciência daquilo que perdeu e do que está continuamente perdendo. E que êle ainda é Homem bastante para sentir sua deshumanização como Desespêro. $E$, embora não saiba qual o caminho, êle continua tentando salvar seu humanismo, seu SER HOMEM, reagindo com coragem contra o Desespêro e resistindo à radical ameaça do NÃO SER pela Coragem de SER. Toda a filosofia de WALDEN resumese em: Salvar o Conteúdo Existencial do Homem e recuperá-lo de seu Desespêro a que se vê reduzido pela perda de sua "entelequia" espiritual: "A massa dos homens leva uma vida de mudo desespêro. O que se denomina resignação não passa de desespêro. De uma cidade desesperada vai-se a um país desesperado, e temos de nos consolar com a intrepidez das martas e dos ratos almiscarados. Um desespêro estereotipado, mas inconsciente, oculta-se até mesmo sob os chamados jogos e divertimentos da humanidade..." (11)

Como locutor na cerimônia da formatura de sua turma, na universidade de Harvard, em 1837, Thoreau escolheu o tema: "O Espírito Comercial". Já então se delineava, em traços marcantes, a atitude fundamental de seu espírito: Este mundo curioso em que vivemos é mais prático do que conveniente; mais lindo do que prático; é mais adequado para ser admirado, gozado do que usufruido. Se é necessária uma ligeira transformação da ordem das coisas, o sétimo dia deveria ser o dia do trabalho para ganhar o dia com o suor do rosto, os outros deveriam ser o Sabath da alma..."(12)

O "self-made-man" da América, o tipo auto-realizado pelas reais conquistas de seu senso prático tudo conseguiu para seu confôrto e sua segurança. Realizou o que Franklin nem sonhara para as futuras gerações americanas quando deixou, como herança, um ról de bene fícios destinados à felicidade doméstica e nacional da América. (13)

11. "The mass of men lead lives of quiet desperation. What is called resignation is confirmed desperation. From the desperate city you go into the desperate country, and have to console yourself with the bravery of minks and muskrats. A stereotyped but unconscious despair is concealed even under what are called the games and amusements of mankind. There is no play in them, for this comes after work. But it is a characteristic of wisdom not to do desperate things". Ibid. WALDEN, p. 7 Trad. C. Neves "A literatura dos Estados Unidos" M.D. Zabel - Agir - 1947.

12. THOREAU - O Rebelde de Concord - A. Derleth - Trad. V.B. Depayti - GRD. 1964 , p. 19.

13. Tinha razāo Carlyle quando denominou a Franklin "pai de todos os yankees", pois, foi Franklin mais que qualquer lider americano, a expressão da vocação da América no papel que desempenharia dentro da civilização moderna. Veja-se como as idéias e invenções do Franklin abriram caminho para o "American Way of Life": A lareira da Pensilvania, o primeiro corpo de Bombeiros, o primeiro papel-moeda da América, a organização dos Correios das colônias, a descoberta do para-raio, a organização da primeira biblioteca pública circulante, o primeiro clube em termos modernos "Junto", suas idéias sôbre a reforma agrária, sôbre a república, os Direitos do Homem, etc. 
De fato, a América superou os mais arrojados sonhos do autor de "The Way to Wealth". O mundo de Franklin do século XVIII, no entanto, não foi senão o início do "American Dream in Action", na subjugação da natureza e do homem para a realização da Grande Sociedade. Estabelecida a era da máquina no século XIX e século XX. veio a Contabilidade Eletrônica garantir a segurança das fascinantes conquistas. A máquina transformou-se em mito, símbolo do Infinito. Já no princípio do século XX previu, Henry Adams, o poder destrutivo e o pesadêlo da velocidade dos modernos meios de comunicação e "nos dínamos de 40 pés uma fôrça moral quase parecida àquela que sentiram os primeiros cristãos na Cruz". (14) A civilização que Henry Adams viu tomar forma nos dínamos, símbolo da fôrça, da masculinidade, do progresso material, apresenta-se, de fato, como uma fôrça desagregadora do humanismo moderno. O predominio da máquina, que transforma a vida do homem e dos aglomerados humanos numa civilização artificial, produz no homem moderno um pânico eufórico. O impacto dos acontecimentos, de sempre novas descobertas, arrojos e riscos, intensificam pânicos coletivos diante do sucesso da técnica, cujas conseqüências os mais argutos não podem avaliar. O espírito humano, colocado entre Deus e o Nada, começa a debruçar-se sôbre si mesmo para meditar. Surge a Consciência existencial em face do pânico da civilização. Essa atmosfera existencialista deixou de ser ambiente exclusivo das elites pensantes para atingir a grande massa dos homens produzindo as mais desencontradas atitudes de espírito. O Medo, o Tédio, o Desespêro provocam, em uns, o cinismo que se desafoga em "sex, liquor and smoke", em outros, em atitudes de desprezo das convençōes, das formas, levando o esfôrço pela autenticidade ao absurdo de novos códigos da juventude, expressos no playboyismo, beatleismo ou "New-Breedism" A geração perdida não se limitou aos "The Roaring Twenties", mas toma vulto e expressão mais radical na década da ameaça atômica. Será esta uma atitude qualificável como nihilista ou como uma tentativa de acomodação ao Século do Mêdo? Uma surpreendente soli dariedade em meio ao cáos do novo "Way of Life" faz crer que sinos metafísicos começam a soar quando se prenuncia o naufrágio da civilização mecanicista do século $X X$. O homem, saturado dos encantos da civilização desagregadora dos primtivos valores humanos, volta-se aos fatos essenciais da vida para reencontrar-se consigo mesmo.

14. "... to Adams the dynamo became a symbol of infinity. As he grew accustomed to the great gallery of machines he began to feel the forty-foot dynamos as a moral force, much as the early Christians felt the Cross". "The American Tradition in Literature-2- S. Bradley, R.C. Beatty, E. H. Long - W.W. Norton \& Company, Inc. $-157-$ p. 426. 
E esta desintegração do humanismo, a inversão ou o desprêzo da hierarquia de valores, a perda da liberdade e da autenticidade hu mana, que produz o pânico da civilização, na interpretação de Henry David Thoreau.

No capítulo: "Where 1 lived and what I lived for", Thoreau resume as razões mais profundas de seu afasłamento da civilização e revela sua fórmula que leva ao retôrno da autenticidade humana e da conscientização da Vida: Ainda vivemos pobremente, como for migas, embora as lendas nos contem, há séculos, que fomos transformados em homens; como pigmeus, lutamos duramente, êrro sôbre êrro, sôco após sôco; e nossas melhores virfudes têm baixeza evitá vel e supérflua... Nossa Vida é malbaratada em pequenos detaIhes... Simplicidade, simplicidade, simplicidade! Eu Ihes digo, dei xem seus negócios serem dois ou três, e não cem ou mil... (15)

No Ensaio "Life Without Principle", Thoreau apresenta o mesmo pensamento de modo mais concreto: Este mundo é um lugar para negócios... nada há que não seja trabalho, trabalho, trabalho: Não há tempo para a meditação e a santificação... Os próprios pensamentos são dominados pelo dolar... Nada há, nem mesmo o crime, que se oponha mais às atividades superiores do homem e à própria vida, que êste incontido espírito comercial.(16)

Ao apresentar seu desencanto da civilização, Thoreau não se refere apenas às deformações do caráter humano individual ou das co munidades por essa incontida ânsia de "this incessant business", refere-se ainda à própria nação em que, conforme sua opinião, predominam os artifícios duma superficial civilização para cura de cujos males só há uma terapêutica: simplificação da vida e espiritualização. "The

15. "Still we live meanly, like ants; though the fable tells us that wa were long ago changed into men; like pygmies we fight with eranes; it is error upon error, and clout upon clout, and our best virfue has for its occasion as superflous and evitable wretcheness. Our life is frittered away by detail. An honest man has hardly need to count more than his ten fingers, or in extreme cases he may add his ten toes, and lump the rest Simplicity, simplicity, simplicity! I say, let your affairs be as two or three, and not a hundred or a thousand'instead of a million count half a dozen, and keep your accounts on your thumb-nail. In the midst of this chopping sea of civilized life, such are the clouds and storms and quicksands and thousand-and-one items to be allowed for, that a man has to live, if he would not founder and go to the bottom and not make his port at all, by dead reckoning, and he must be a great calculator indeed who succeeds, Simplify, Simplify". WALDEN - The Modern Library - 1950 - N.Y., p. 82.

16. This world is a place of business. What an infinite bustle! $I$ am awaked almost every night by panting of thelocomotive. It inferrupts my dreams. There is no sabbath. It would be glorious to see mankind at leisure for once. It is nothing but work, work, work. I cannot easily buy a blankbook to write thoughts in'they are commonly ruled for dollars and cents... I think that there is nothing, not even crime, more opposed to poetry, to philosophy, ay, to life itself, than this incessant business. "Ibid. WALDEN. p. 712. 
nation itself, with its so-called internal improvements, which, by the way, are all external and superficial, is just such an unwildly and evergrown establishment, chuttered with furniture and tripped up by its own traps, ruined by luxury and heedless expense, by want of calculation and a worthy aim, as the million house-holds in the land; and the only cure for it, as for them, is in a rigid economy, a stern and more than Spartan simplicity of life and elevation of purpose".(17)

E sintomático que os dois escritores americanos, que, no apogeu do romantismo, consideraram o grande "rush" para o oeste, impulsionado pelo "gold fever", uma desgraça para a nação, ou melhor, uma ameaça ao sadio humanismo americano, foram, justamente êles, os escritores mais representativos da angústia existencial que se prenunciava: Edgar Allan Poe e Henry David Thoreau. Poe, ao escrever o poema "El Dorado", em 1849, quando se iniciava o "rush", expressa na figura de "a pilgrim shadow" a tônica da desilusão. No poema "The City in the Sea" o mesmo Poe, depois de descrever o cataclismo e a desolação a que pressente reduzidas as mais fascinantes realizações do Oeste, vê, além dos prejuizos da hecatombe material, a angústia dos espíritos, o desespêro e a morte do Homem. Em "Life Without Principle", Thoreau tira idêntica conclusão: "The rush to Ca. lifornia, for instance, and the attitude, not merely of merchants, but of philosophers and prophets, so called in relation to it, reflect the greatest disgrace on Mankind."(18) E ainda: "The gold-digger in the ravines of the mountains is as much a gambler as his fellow in the salloons of San Francisco. What difference does it make whether you shake dirt or shake dice? If you win, society is the loser."(19) Poe e Thoreau nada mais quiseram exprimir senão a desconfiança do sucesso e das fantásticas conquistas materiais, que, com suas implicações, não fariam mais felizes nem o homem nem a nação. Ao mesmo pensamento, hoje transformado em angústia coletiva, dá expressão, John dos Passos, em "Manhattan Transfer": There were Babylon and Nineveh; they were built of brick. Athens was gold marble columns. Rome was held upon broad arches of rubble. In Constantinople the minarets flame like great candles round the Golden Horn... Steel, glass, tile, concrete will be the materials of the skyscrapers. Crammed on the narrow island the million-windowed buildings will jut glittering, pyramid on pyramid like the white cloudhead above a thunderstorm".(20)

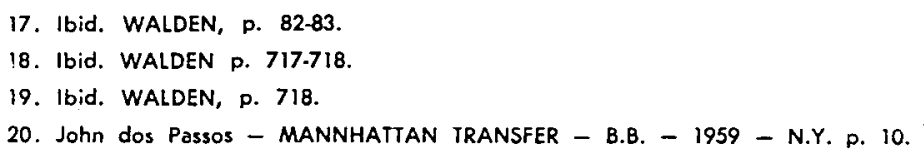




\section{HOMO OECONOMICUS}

A interpretação da ordem bíblica do domínio da terra pelo homem, representa um desafio à grandeza da inteligência humana, como pode constituir-se em ameaça à integridade do homem. No caminho do progresso revela-se a dualidade humana em tôda sua dinâmica existencial: Homem-Espírito e Homem-Matéria. Surge o conflito dos valores relativos e absolutos e da irreversibilidade da condição humana no Espaço, no Tempo, na Eternidade. O "Homo Oeconomicus" defronta-se com o conflito entre as economias do Tempo e da Eternidade, do Espírito e da Matéria. Conservar a sua integridade no trato com a terra, atendendo à dinâmica da condição humana, converte-se em sentido da própria existência. Como colaborador do processo da civilização, o homem está sujeito à ameaça de integrar-se de tal forma na Oeconomia material a comprometer sua integridade e liberdade expondo sua condição humana a tôdas as conseqüências e aos efeitos da servidão da matéria. No seu tratado "Economy", pergunta Thoreau: "Who made them serfs of the soil? Why should they eat their sixty acres, when man is condemned to eat only his peck of dirt?X Why should they begin digging their graves as soon as they are born? They have got to live a mans life, pushing all these things before them, and get on as well as they can. How many a poor immorta! soul have 1 met well-nigh crushed and smothered under its load, creeping down the road of life, pushing before it a barn seventy-five by forty, its Augean stables never cleansed, and one hundred acres of land, tillage, mowing, pasture, and wood-lot! The portionless, who struggle with no such unnecessary inherited encumbrances, find it la. bor enough to sundue and cultivate a few cubic feet of flesh.(21)

Salvar a integridade da condição humana, em meio a superfluidades e exterioridades duma civilização que o próprio homem crio's para a sua insofreguidão, e, restabelecer a hierarquia dos valores, e, com ela, o equilíbrio da dualidade humana é o princípio básico da "Oeconomia" de Thoreau. "Economy" é uma espécie de Bíblia de reformas mais de homens que de coisas. "Walden" é, todo êle, um brado de retôrno às terras virgens da sociedade humana, ou, como diz o próprio Thoreau "to live a primitive and frontier life", onde o homem possa reencontrar-se consigo mesmo e redescobrir as verda. deiras causas de sua inquietação. "Let us consider for a moment what most of the trouble and anxiety which I have referred to is about, and how much it is necessary that we are troubled, or a least careful. It would be some advantage to live a primitive and frontier life, thougin in the midst of an outward civilization, if only to learn what are the

21. Ibid. WALDEN, p. 5. 
gross necessaries of life and what the methods have been taken to obtain them; or even to look over the old day-books of the merchants, to see what it was that men most commonly bought at the stores, what they stored, that is, what are the grossest grocerie. For the improvements af ages have had but little influence on the essential laws of man's existence: as our skeletons, probably, are not to be distinguished form those of our ancestor."(22)

O homem, colocado diàriamente diante da opção entre o Essen. cial e o Acidental, entre as facilidades da vida material e a austeridade da vida espiritual, angustia-se quando não atende às íntimas exigências de sua "entelequia" existencial. Dominado pela azáfama do mundo moderno que dita ritmos da pressa e da audácia, da mobilidade das massas, desperdiça, o homem, a substância de sua Vida. E, por isso, que Thoreau pergunta: "Why should we live with such hur. ry and waste of life?"'(23) Forma-se o tipo psico-morfológico do homem da era mecanicista, incapaz de livrar-se da dança coletiva que Thoreau chama de "Saint Vitus's Dance", que é a enfermidade da inquiełação nervosa e psíquica que se manifesta na mobilidade incontrolável de sensações: "We have the Saint Vitus's dance, and cannot possibly keep our heads still."(24).

Em sua análise do homem moderno, Thoreau usa a figura de Ulisses, protótipo do homem irriquieto, errante ou equivocado em jornadeios sem fim. 'With unrelaxed nerves, with morning vigor, sail by it, looking another way, tied to the mast like Ulisses. If the engine whistles, let it whistle till it is hoarse for its pain. If the bell rings, why should we run? We will consider what kind of music they are like. Let us settle ourselves, and work and wedge our feet downward through the mud and slush of opinion, and prejudice, and tradition, and delusion, and appearance, that alluvion which covers the globe, through Paris and London and Concerd, through Church and State, through poetry and philosophy and religion, till we corre to hard bottom and rocks in place, which we can call Reality..."(25)

H.D. Thoreau, apresentando sua "Oeconomia" de salvação do homem, detém-se na indicação da profilaxia da enfermidade a que sucumbe o homem no processo descontrolado da civilização. Nã descrê, porém, que uma adequada terapêutica possa libertar o homem da complexidade de seu mundo interior e da servidão de seu mundo exterior. Para tanto urge, Thoreau, o restabelecimento da Ordemi Su-

22. Ibid. WALDEN, p. 10-11.

23. AN AMERICAN READER - J.8. Faweet, p. 85.

24. Ibid. 85-86.

25. Ibid. p. 86 . 
perior da Existência. Nela o homem encontra suas verdadeiras me tas e realiza seus sonhos existenciais. E, assim, na proporção que 0 homem simplifica a sua vida, as leis do universo the parecerão menos complexas, e a solidão deixará de ser solidão, a pobreza não será pobreza nem a fraqueza será fraqueza. Mesmo que o homem che. gue à conclusão de que construiu castelos no ar, sua obra não está necessàriamente perdida. Elles estão onde devem estar. Necessário é, no entanto, que se lhes coloquem os fundamentos. "I learned this, at least, by my experiment: that if one advances confidently in the direction of his dreams, and endeavors to live the life which he has imagined, he will meet with a success unexpecter in common hours. He will put some things behind, will pass an invisible boundary; new, universal, and more liberal laws will begin to establish themselves around and within him; or the old laws be expanded, and interpreted in his favor in a more liberal sense, and he will live with the license of a higher order of beings. In proportion as he simplifies his life, the laws of the universe will appear less complex, and solitude will not be solitude, nor poverty poverty, nor weakness weakness. If you have built castles in the air, your work need not to be lost; that is where they should be. Now put the foundations under them".(26)

Thoreau termina "WALDEN" dando ênfase à verdadeira "entelequia" do homem e a transforma numa vivência existencial, síntese que reúne, numa descoberta reveladora, o passado, o presente e o futuro do homem.: "The government of the world I live in was not framed... Who does not feel in a ressurection and immortality strengthened by hearing this?... Such is the character of that morrow which mere lapse of time can never make to dawn. The light which puts out our eyes is darkness to us. Only that day dawns to which we are awake. There is more day to dawn. The sun is but a morning star".(27)

\section{HOMO AETERNUS}

\section{"Read not the Times. Read the Eternities." - Thoreau LIFE WITHOUT PRINCIPLE}

Thoreau não se detém, em sua análise, ao culpar a civilização, a técnica, o comercialismo, a inautenticidade das instituições que, sob as aparências do aperfeiçoamento da vida, deturpam a condição hu. mana; insurge-se, Thoreau, contra o próprio esquema do cristianismo. Suas afirmações sôbre distorções, que justificam uma distinção entre cristianismo e cristandade, apontam afinidade com conceitos de S. Kierkegaard em "A Hypocrital Generation", e, com Dostojewsky em

26. Ibid. WALDEN, p. 288.

27. Ibid. WALDEN, p. 296-297. 
"Christ and the Grand Inquisitor", quando afirma que se Cristo hoje tornasse a aparecer sôbre a terra, Ele seria denunciado como um equivocado, insano, louco. "If Christ should appear on earth he would on all hands be denounced as a mistaken, misguided man, insane and crazed."(28)

De fato, H.D. Thoreau não foi um cristão, no sentido estrito da palavra. Combateu as instituições religiosas. Considerava-as inautênticas e nocivas à integridade de seu mundo espiritual. Sempre à procura de uma vivência mais pura, insurgiu-se contra tôdas as instituições, também religiosas, que o pensamento humano pudesse deturpar. Renunciou à filiação de sua igreja por um documento oficial: "O Estado veio ao meu encontro, como representante da lgreja e ordenou-me pagar determinada soma para a manutenção de um clérigo cujos sermões meu pai frequentava, mas não eu... Recusei-me a pagar. Entretanto, a pedido dos "Selectmen", consenti em fazer por escrito a seguinte declaração: "Saibam todos que pela presente, eu Henry Thoreau, renuncio a ser considerado membro de qualquer sociedade incorporada em que não me tenha inscrito." Dei-a ao oficial da Justiça da cidade, que a guarda até hoje. O Estado, tomando assim conhecimento de que não quero ser considerado membro daquela igreja, nunca mais me fêz exigência semelhante. . ."(29)

Com a lgreja Católica teve alguns contactos, p.ex., através de Isaac Hecker, que se converteu ao catolicismo e que o convidou a acompanhá-lo numa viagem pelo continente, convite que Thoreau re. cusou. Uma das mais veementes acusações que Thoreau dirige à lgreja Católica é com referência à instifucionalização da confissão que con sidera uma auto-ludibriação. "On Sundays the poor debtor goes to church to take an account of stock, and finds, of course, that his outgoes have been greater than his income. In the Catholic Church, especially, they go into Chancery, make a clean confession, give up all, and think to start again. Thus men will lie on their backs, talking about the fall of man, and never make an effort to get up."(30)

A atifude fundamental de Thoreau foi a de uma constante, inso frida procura. O passado, o presente e o futuro, a Vida e a Morte, a Eternidade constituem o elan para suas elocubrações existenciais. "In any weather, at any hour of the day or night, I have been anxious to improve the nick of time, and notch it on my stick too; to stand on the meeting of two eternities, the past and the future, which is precisely the present moment." (31)

28. THE LIVING THOUGHTS OF THOREAU - Th. Dreiser - Fawceit World Library - p. 124.

29. THOREAU, O REBELDE DE CONCORD - A. DERLETH - Trad. de V.B. Delayti, p. 61.

30. WALDEN, 716.

31. WALDEN, 15 
Em 1842, numa das maiores crises de sua vida, Thoreau exclama em seu "Diário": "Minha Vida, ó minha Vida! Por que razão prossegues? Serão os anos curtos, não se contarão os Meses? Quantas vêzes uma demora prolongada extinguiu minha:s aspirações! Pode Deus suportar que eu $O$ esqueça?... Por que, Deus, estou incluído em Vosso grande esquema? Não me tornareis, enfim, um compa. nheiro?"

Quando Thoreau resume sua atitude fundamental no princípio "Read not the Times. Read the Eternities", êle abstrai, também, no campo religioso, de tôda materialidade ou terrenidade que possa des. virtuar a essência da vivência religiosa. Há nisto um vestígio da primitiva inocência humana que se angustia ao descobrir que não the é permitido usufruir a harmonia, porque ela já não existe no paraíso perdido. A condição humana é outra. Reside no história americana, marcadamente nos seus primórdios, no bíblico anseio dos peregrinos, essa vivência do paraíso perdido como todo um conteúdo religioso de almas angustiadas que, impelidas por uma eterna saudade, quiseram fazer de sua peregrinação uma experiência existencial eliminando do seu "way of life" tudo que pudesse ofuscar a consciência do Eterno.

\section{SAINTE-TERRER}

H.D. Thoreau escreveu, pouco antes de sua morte, um dos mais expressivos documentos de sua alma de peregrino: "WALKING", publicado quatro semanas depois de seu desenlace. em 1862, em "The Atlantik Monthly". Nesse "extreme statement", Thoreau diz que, no curso de sua vida, não encontrou senão uma ou duas pessoas que conheceram a arte da peregrinação, que tiveram o gênio de empreender o que êle chama de "Sautering", palavra que traduz por "Holylander", peregrino que se dirige à Terra Santa e do qual, ao verem no pedir caridade, exclamam as crianças: "There goes a Sainte-Terrer!" Aquêles que nunca procuraram a Terra Santa em suas peregrinações, considera Thoreau, "idlers and vagabonds". Thoreau traduz a palavra "Sainte-Terrer" por homem sem terra, "sans terre", que, não tendo lar nem terras, sente-se em casa em qualquer lugar do mundo. Considera êle esta condição humana o fundamento da experiência religiosa. Ser peregrino é para Thoreau graça que vem de Deus: "We have felt that we almost alone hereabouts practiced this noble art; though, to tell the truth, at least, if their own assertions are to be received, most of my townsmen would fain walk sometimes, as I do, but they cannot. No wealth can buy the requisite leisure, freedom, and independence which are the capital in this profession. It comes only by the grace of God. If requires a direct dispensation from 
Heaven to become a walker. You must be borr into the family of the walkers".(32)

Foi esta a condição humana que os peregrinos do "Mayflower" sonharam para a América. Este Ideal religioso é contrário ao confinamento claustral e implica uma mobilidade constante para atingir tôda experiência existencial. Thoreau completa o fensamento dizendo que há os que se confinaram a si mesmos "to the highway ever sin. ce". Também êsses são elevados por momentos. e, mesmo que "foresters and outlaws", podem atingir esta elevação "as by the reminiscence of a previous state of existence".(33)

Thoreau desenvolve tôda uma mística do peregrino da América: "Walk out into a Nature such as the old prophets and poets, Menu, Moses, Homer, Chaucer, walked in. You may name it America, but is it not America; neither Americus Vespucius, no: Columbus, nor the rest were the discoverers of it. There is a truer account of it in my. thology than in any history of America, so called, that I have seen". (34)

Depois de apreciar os postulados da autenticidade e as conseqüências da apostasia da vocação do "saunterer' americano que se detém, em sua peregrinação, na ilusão dos bens terrenos, nos fenômenos superficiais e acidentais da existência, Thoreau apresenta as autênticas belezas que o peregrino descobre em sua jornada: "The sun sets on some retired meadow, where no house is visible, with all the glory and splendor that it lavishes on cities, and perchance as it has never set before-where there is but a solitary arsh-hawk to have his wings gilded by it, or only a muswash looks out from his cabin, and there is some little black veined brook in the midst of the marsh, just beginning to meander, winding slowly round a decaying stump. We walked in so pure and bright a light, gilding the withered grass and leaves, so softly and serenely bright, I thought I had never bathed in such a golden flood, without a ripple or a murmur to it. The west side of every wood and rising ground gleamed like the boundary of Elysium and the sun on ourn backs seemed like a gentle herdsman driving as home at the evening".(35) Feita a descoberta do ambiente místico que cerca a existência, na sua primeva beleza, Thoreau conclui para a outra existência que um sol há de iluminar com um brilho capaz de acordar para a eternidade. "So we saunter toward the Holy Land, till one day the sun shall shine more brightly than ever he has done, shall perchance shine into our minds and hearts, and light

32. WALKING, ibid. 598

33. Ibid. WALKING, 599

34. Ibid. WALKING, 604.

35. Ibid. WALKING, 631-632. 
up our whole lives with a great awakening light, as warm and serene and golden as on a bankside in autumn".(36)

Apesar de tôdas as invectivas contra religiōes institucionalizadas em que vê marcas de deficiências humanas, Thoreau apresenta, em sua atitude fundamental, uma afinidade com as mais lídimas páginas do evangelho. Uma sintonia perfeita encontra-se na renúncia à matéria, à riqueza, até aos bens, em si permitidos, da terra, renúncia que se constitui em atitude fundamental para a própria perfeição cristã: "If you are ready to leave father and mother, and brother and sister, and wife and child and friends, and never see them again, - if you have paid your debts, and made your will, and settled all your affairs and are a free man, then you are ready for a walk".(37)

A angústia thoreauana é a inconformidade com as facetas humanas que o homem encontra ao constatar a impossibilidade da realização perfeita da face divina do evangelho que foi entregue aos homens. O próprio Cristo é objeto de sua intransigência por falar a linguagem dos homens para ser entendido, mesmo quando fala das coisas divinas aos homens da terra.(38) Apesar das contradiçōes ao evangelho e ao próprio Cristo que encontramos na obra de Thoreau, há passagens reveladoras duma sintonia admirével com o espírito cristão ou de uma intuitiva adesão: "What is religion? That which is never spoken. Consider the dawn and the sunrise - The rainbow and the evening - the words of Christ and the aspiration of all saints!"(39) As causas de sua inconformidade no campo religioso residem no mistério da dualidade humana. Situam-se aí, no MistérioHomem, as causas de seu dilema existencial - "Every man is the builder of a temple, called his body, to the God he worships, after a style purely of his own, nor can he get off by hammering marble instead. We are all sculptors and painters, and our material, is our own flesh and blood and bones".(40) Ou, em outra passagem: I see, smell, taste, hear, feel, that everlasting Something to which we are allied, at once our maker, our abode, our destiny, our very Selves..." (41)

A idéia da Morte foi para Thoreau a mais presente em sua consciência confundindo-se com a idéia da Vida ou, complementando-a.

36. Ibid. WALKING, 632.

37. Ibid. WALKING, 555.

38. Christ was a sublime actor on the stage of the world... Yet he taught mankind but imperfectly how to live; his thoughts were all directed toward another world. There is another kind of success than his. Even here we have a sort of living to get, and must buffet it somewhat longer. THOREAU - Th. Dreiser, 122.

39. THOREAU - Th. Dreiser, p. 121.

40. WALDEN, 99.

41. THOREAU - Th. Dreiser, 41 . 
O axioma da mística medieval: "in medio Vitae sumus", era sua constante vivencia: "Death is as natural as Life because Life Lives on Life... Our thoughts are with those among the dead into whose we are rising, or who are rising into our own".(42)

Em última análise, foi a fundamental, incessante "business" de H.D. Thoreau: Conciliar as "two eternities" que são, em sua concepção existencial: Vida e Morte que, somadas, formam a Eternidade. Tempo para êle não é um acidente apenas, mas ocupa um lugar de destaque na fórmula para a equação do problema existencial e para sua solução. E sôbre o Tempo que Thoreau escreveu uma das mais belas páginas da prosa americana:- O Tempo não é senão o rio, onde vou pescar. Ao beber de suas águas, vejo o fundo arenoso, percebo como é raso. Sua corrente é estreita; êle desliza lentamente; mas a eternidade permanece. Eu, de boa vontade, beberia mais, pescaria nos céus calçados de seixos redondos, que são as estrêlas. Não posso contar uma sequer, desconheço a primeira letra do alfabeto. Sempre lamento não ser mais sábio como no dia em que nasci: o intelecto é um cutelo que descobre e abre caminho dentro do âmago secreto das coisas. Não busco nunca ter minhas mãos mais ocupadas do que seja estritamente necessário. Minha cabeça são minhas mãos e meus pés. Sinto que tôdas as minhas melhores faculdades nelas se concentram. $O$ instinto me diz que minha cabeça é um órgão para cavar; uso-a exatamente como outras criaturas usam o focinho e as patas dianteiras; com ela cavarei um túnel através das montanhas. Acho que o veio mais rico es:á bem perto daqui; deduzo-o por minha varinha de condão, pelos vapores efêmeros; aqui mesmo começarei a cavar".(43) .Foi, com estas palavras, que Thoreau encerrou, em WALDEN, suas considerações sôbre: "Where I lived, and what I lived for".

Para Thoreau as ações do espírito dão significação às ações do corpo. E o término das ações do tempo representa o início das ações da eternidade. E, por isso, que Thoreau considera a Morte o grande Início: 'We are ever dying to one world and being born into ano-

42. THOREAU, Th. Dreiser, p. $168,175$.

43. "Time is but the stream I go a-fishing. I drink at it; but while I drink I see the sandy bottom and defect how shallow it is. Its eurrent slides away, but eternity remains. I would drink deeper; fish in the sky whose bottom is pebbly with stars. I cannot count one. I know not the first letter of the alphabet. I have always been regretting that I was not as wise as the day 1 was born. The infellect is a cleaver; it discerns and rifts their snout and four paws, and with it I would mine and burrow my way through these than is necessary. My head is hands and feet. I feel all my best faculties concentrated in it. My instinct tells me that my head is an organ for burrowing, as some creatures use their snout and four paws, and with it I would mine and burrow my way through these hills. I think that the richest vein is somewhere hereabouts; so by the divining-rod and thin rising vapors 1 judge; here $i$ will begin to mine". WALDEN, 89. 
ther, and possibly no man knows whether he is at any time dead in the sense in which he affirms that phenomenon of another, or not." (44)

Thoreau, embora admitindo que a Vida pode ser julgada um drama e, até uma tragédia, considera a perspectiva do Infinito uma Solidão confortante: "When the play, it may be the tragedy of life, is over, the expectator goes his way... I find it wholesome to be alone the greater part of the time... I love to be alone".(45) O desaparecimento da terrenidade e do tempo é o verćadeiro Acordar que tornam indiferentes os acidentes, lugares e condições passadas, despertam a consciência do céu e da terra exercendo uma influência purificadora sôbre o Homem: "Any prospect of awakening or coming to life to a dead man makes indifferent all times and places... how vast and profound is the influence of the subtile powers of Heaven and Earth! We seek to perceive them, and we do not hear them; identified with the substance of things, they cannot be separated from them. They cause that in all the universe men purify and sanctify their hearts, and clothe themselves in their holyday garments to offer sacrifices and oblations to their ancestors. It is an ocean of subtile intelligences. They are everywhere, above us, on our left, on our right; they environ us on all sides.(46)

O problema angustiante não é a morte. Ela é de aceitação serena, na concepção thoreauana. O problema é: Conservar, na Vida, a Solitude que possibilita a Ação do Espírito e a Conscientização da Eternidade. Não são os fatos e os acidentes que determinam as épo cas de nossas vidas, mas "Our thoughts are the epochs of our life! All else is but as a journal of winds that blew while we were here". (47)

A grande Conclusão que avulta do emaranhado do pensamento existencial de H.D. Thoreau se resume na sua preocupação constante de não desperdiçar valor algum nem instante algum da preciosa existência do homem. Daí sua exigência que dirige ao homem: Penetrar a fundo nos mistérios da Vida e da Morte, antes de começar a Viver a Vida da própria Individualidade. E daí sua sugestão: Conhecer nosso $A B C$ o mais cedo possivel: 'We have got to know what both Life and Death are, before we can begin to live after our own fashion. Let us be learning our A-B-Cs as soon as possible".(48)

\footnotetext{
44. THOREAU - Th. Dreiser, 167-68.

45. WALDEN, 122.

46. WALDEN, 121-122.

47. THOREAU - Th. Dreiser, 168.

48. THOREAU - Th. Dreiser, 169.
} 